\title{
Behavioural response of wheat bulb fly (Delia coarctata, Diptera: Anthomyiidae) larvae to the primary plant metabolite carbon dioxide
}

\author{
C.D. Rogers ${ }^{1,2 *}$, K.A. Evans ${ }^{2}$, J. Parker ${ }^{2}$ and V.A. Pappa ${ }^{3}$ \\ ${ }^{1}$ Institute of Evolutionary Biology, University of Edinburgh Ashworth \\ Laboratories, Edinburgh EH9 3JT, UK: ${ }^{2}$ SRUC, West Mains Road, Edinburgh \\ EH9 3JG, UK: ${ }^{3}$ Züricher Hochschule für Angewandte Wissenschaften, \\ Institut Umwelt und Natürliche Ressourcen, Grüental 8820, Wädenswil, \\ Switzerland
}

\begin{abstract}
Wheat bulb fly (WBF) larvae use chemotaxis to orientate towards host-plant root exudates. This study aimed to investigate the role of the primary plant metabolite carbon dioxide $\left(\mathrm{CO}_{2}\right)$ in host-plant location by WBF. Arena based behavioural experiments were used to identify whether $\mathrm{CO}_{2}$ induced chemotaxis (directional movement in response to a chemical stimulus) or kinesis (non-directional movement in response to a stimulus) from WBF larvae. No chemotactic response was observed when larvae were presented to a point source of $\mathrm{CO}_{2}$. However, elevated levels of $\mathrm{CO}_{2}$ induced kinesis, with both track length and tortuosity (number of twists and turns in the movement path) increasing at elevated $\mathrm{CO}_{2}$ levels of $1000-2000 \mathrm{ppm}$, demonstrating increased searching behaviour. Soil emission of $\mathrm{CO}_{2}$ was quantified to compare soil levels with those identified as eliciting behavioural effects on the larvae. Samples removed from soil gave a mean $\mathrm{CO}_{2}$ concentration of $557( \pm 46) \mathrm{ppm}$, which is lower than the lowest concentration of $\mathrm{CO}_{2}$ found to induce a behavioural response and higher than the lowest $\mathrm{CO}_{2}$ concentration tested, which was found not to alter behaviour. It is proposed that increased $\mathrm{CO}_{2}$ concentrations in the soil act as a behavioural trigger, inducing intensive searching of an area by WBF larvae. This increases the likelihood of finding more host-specific identifiers, such as secondary metabolites when near a potential host-plant.
\end{abstract}

Keywords: chemical ecology, $\mathrm{CO}_{2}$, host location, pest, phytophagous, semiochemical

(Accepted 30 May 2013; First published online 10 July 2013)

\section{Introduction}

Primary and secondary metabolites exuded by plants are utilized by soil-dwelling phytophagous insect larvae to locate

*Author for correspondence

Fax: +44 (0)1315354144

Phone: +44 (0)7725649393

E-mail: craigrogers22@hotmail.com and identify host-plant species (Johnson \& Gregory, 2006; Johnson \& Nielsen, 2012). Secondary plant metabolite attractants generally include species, genus and familyspecific chemicals that may allow both monophagous and oligophagous larvae to identify their specific host-plants (Johnson \& Gregory, 2006). Primary plant metabolites are metabolites directly involved in essential plant processes and are thus ubiquitous to all plants (Taiz \& Zeiger, 2010). Primary plant metabolites such as carbon dioxide $\left(\mathrm{CO}_{2}\right)$ and carbohydrates have been shown to have an important role in 
host-plant location in a number of insect species (Thorpe et al., 1947; Strnad et al., 1986; Honda \& Ishikawa, 1987; Galbreath, 1988; Hopkins et al., 1993; Huang \& Mack, 2001; Johnson et al., 2006), including a number important to agriculture, such as Diabrotica spp. (corn rootworm, Strnad et al., 1986; Jewett \& Bjostad, 1996), Agriotes spp. (wireworm, Klingler, 1957), Delia radicum (cabbage root fly, Jones \& Coaker, 1978) and Psilia rosae (carrot root fly, Jones \& Coaker, 1977).

Despite being found to induce behavioural changes in a number of soil-dwelling phytophagous insects, $\mathrm{CO}_{2}$ gradients as a means for host-plant location is difficult to conceive, due to: (1) The universal production of $\mathrm{CO}_{2}$ by plants prevents distinction from host and non-host species. (2) There are a number of potential non-host point sources of $\mathrm{CO}_{2}$ in the soil such as microbial interactions (Hanson et al., 2000). (3) Interaction between atmospheric and soil $\mathrm{CO}_{2}$ concentrations disrupt $\mathrm{CO}_{2}$ gradients from plants (Gollany et al., 1993; Sheppard \& Lloyd, 2002).

In some systems, $\mathrm{CO}_{2}$ has been proposed as being attractive to host-plant seeking insects, with larvae orientating towards a source (Jones \& Coaker, 1977; Jewett \& Bjostad, 1996). However, for species such as Sitona lepidus (clover weevil) no attraction has been demonstrated, but behavioural changes are observed when larvae are exposed to concentrations of $\mathrm{CO}_{2}$ comparable with that found around the root system of its host-plant (Johnson et al., 2006). It has been suggested that $\mathrm{CO}_{2}$ does not always play a direct role in identifying suitable hosts in the subterranean environment, but plays a role in initiating searching behaviour (Johnson et al., 2006; Hiltpold \& Turlings, 2012; Johnson \& Nielsen, 2012; Turlings et al., 2012). Understanding the mechanisms underpinning host-plant location in pest species can be keyed to the development of novel pest control strategies.

Delia coarctata (Fallén, Diptera: Anthomyiidae, wheat bulb fly (WBF)) oviposit in bare and exposed soil such as that colonized by its suspected natural host couch grass (Elytrigia repens) (Marriott \& Evans, 2003). In agricultural environments, WBF display a preference for fallow ground or fields containing potato, sugar beet and open canopy vegetables (Petherbridge, 1921; Morris, 1925). Often, crop rotations result in wheat (Triticum aestivum L.) being sown after these crops, allowing WBF larvae to infest vulnerable wheat seedlings when the eggs hatch in January and February (Way, 1959). Since the eggs are not laid in association with a host-plant (Petherbridge, 1921), hatching larvae are required to seek out host-plants quickly before energy reserves run out.

Wheat bulb larvae have been shown to display positive taxis towards exudates of host-plants (Marriott \& Evans, 2003; Rogers \& Evans, 2013). However, no research has looked at the role of primary plant metabolites such as $\mathrm{CO}_{2}$ in host-plant location by WBF larvae. The studies on WBF larval behavioural responses to exudates and chemical constituents have previously concentrated on analysing the final resting position of the larvae or observing movement to a source (Stokes, 1956; Scott, 1974; Greenway et al., 1976; Marriott \& Evans, 2003; Rogers \& Evans, 2013), and these methodologies simply allow the description of attraction or repellence. However, valuable information contained in the movement path of the larvae is not recorded.

Analysis of the tracks left by insects exposed to semiochemicals can provide evidence of the role these chemicals play in the insects' ecology (Nams, 2005). The analysis of the fractal dimension of track shape is commonly used to interpret tracks left by animals (Doerr \& Doerr, 2004). The fractal dimension of a track shape allows the inference of the behaviour of the animal based on its movements (Nams, 1996). The lower the fractal dimension value attributed to a track in a homogeneous environment the more direct the animal is moving from one point to another, suggesting movement between resource patches (Wiens et al., 1995). However, a higher fractal dimension associated with a more tortuous track can indicate searching behaviour within a resource, with the area being covered more intensively.

Understanding the chemical ecology of WBF allows the potential to develop new control measures that can lessen the current dependence on the use of organophosphate insecticides in control of this species. The aim of this study was to observe the behavioural response of WBF larvae in relation to $\mathrm{CO}_{2}$. Bioassays were conducted to identify whether larvae orientated towards a point source of $\mathrm{CO}_{2}$ (chemotaxis) (Adler, 1966; Eisenbach, 2004) or alter their searching behaviour (turning pattern, indicated by a change in fractal dimension) in the presence of differing concentrations of $\mathrm{CO}_{2}$ without moving towards the source (kinesis) (Gillott, 2005). Finally, the concentration of soil $\mathrm{CO}_{2}$ in relation to hostplant seedlings was determined to relate the bioassay response to $\mathrm{CO}_{2}$ to the concentration typically encountered by WBF larvae in soil.

\section{Materials and methods Biological material}

Field collected WBF eggs were surface sterilized with $0.3 \%$ $\mathrm{NaOCl}$ before being rinsed in sterile distilled water (Bellows \& Fisher, 1999; Marriott, 2001). The eggs were stored between sections of nylon, positioned on top of moist vermiculite in a sealed $90 \mathrm{~mm}$ Petri dish. Eggs were stored at $5^{\circ} \mathrm{C}$ for at least 2 months; methyl paraben was added to the eggs to control fungal infections as required. Eggs were stored at $10^{\circ} \mathrm{C}$ to initiate hatching after the two month diapause had elapsed, and larvae were used within $24 \mathrm{~h}$ of hatching, with individual larvae used once only.

Wheat seeds (cv. Aristos) were surface-sterilized in 3\% $\mathrm{NaOCl}$ solution for $2 \mathrm{~min}$, before being thoroughly rinsed in sterile distilled water. The seeds were then germinated in $90 \mathrm{~mm}$ Petri dishes containing 0.3\% technical grade agar under sterile conditions. The seeds were germinated in the dark at $13^{\circ} \mathrm{C}$ for 7 days (until coleoptiles were at least $80 \mathrm{~mm}$ in length), before being used in the experiment.

\section{$\mathrm{CO}_{2}$ as an attractant}

Larval tracks were observed in circular arenas consisting of a $90 \mathrm{~mm}$ diameter Petri dish with an inlet and an outlet valve at opposite sides of the arena (fig. 1). The base of the arena was lined with a 5-mm thick film of agar (Oxoid, Technical grade $0.3 \%$ ), while an opening on the lid allowed access for placement of test larvae, without disrupting the atmosphere of the arena. A cap coated with petroleum jelly was used to seal the opening during the experiment.

A constant stream of $\mathrm{CO}_{2}(>99 \%)$ or $\mathrm{CO}_{2}$-free air (BOC, UK) (absorbed using sodium hydroxide (Tepe \& Dodge, 1943)) was pumped into the arena at $8 \mathrm{mlh}^{-1}$ (the most attractive rate found by Jones \& Coaker, 1977; Johnson et al., 2006), while air was drawn out of the arena directly opposite the inlet at the same rate. The $\mathrm{CO}_{2}$ gradient was allowed to build for $1 \mathrm{~h}$ before a larva was introduced into the centre of 


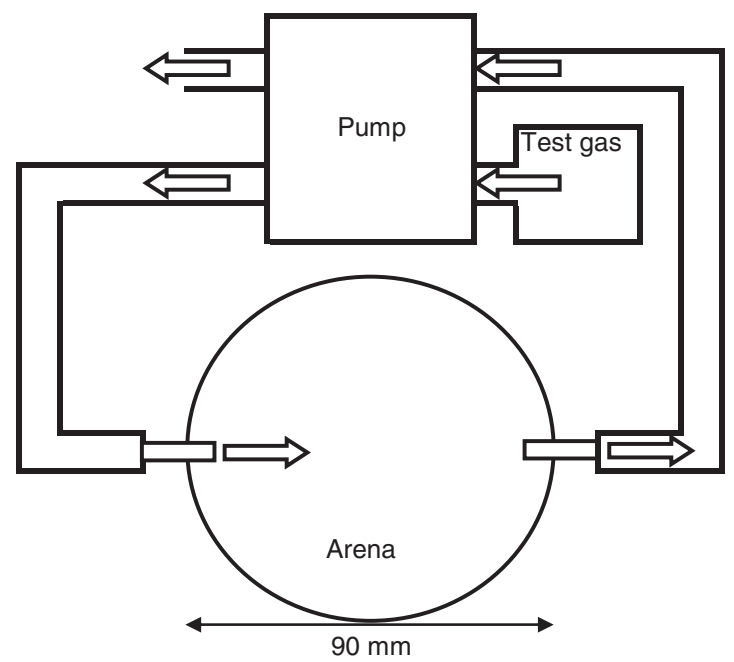

Fig. 1. Diagram of area bioassay used to record the behavioural response of WBF larvae to different concentrations of $\mathrm{CO}_{2}: 0,380$, 1000, 1500, 2000 and $2500 \mathrm{ppm}$. Direction of system airflow indicated by: $\Longrightarrow$.

the arena, presenting it towards the airflow. Arenas were stored in the dark at $18 \pm 2^{\circ} \mathrm{C}$ for $20 \mathrm{~min}$ after which the larval track visible on the agar film was traced on to the base of the arena, and the number of larvae that moved to within $20 \mathrm{~mm}$ of the inlet were recorded. The number of individuals tested for each treatment was 20, with each larva being used once only.

\section{$\mathrm{CO}_{2}$ as a behavioural modifier}

Larvae were released in the centre of Petri dish arenas (the same as described in the previous experiment), which were then sealed and saturated with specific concentrations of either $\mathrm{CO}_{2}$ : 380 (ambient), 1000, 1500, 2000 and 2500 ppm, or a control consisting of $\mathrm{CO}_{2}$-free air. $\mathrm{CO}_{2}$ concentrations were verified using a $\mathrm{CO}_{2}$ meter (Gascard II, Edinburgh Instruments Ltd.). Larval start position was recorded and arenas were stored in the dark at $18 \pm 2^{\circ} \mathrm{C}$ for $20 \mathrm{~min}$, after which the resulting larval track visible on the agar film was traced on to the base of the arena. Tracks were digitized and $x-y$ co-ordinates for the tracks were captured. The number of individuals tested for each treatment was 20, each larva being used once only.

\section{Behavioural statistical analysis}

Larval attraction to $\mathrm{CO}_{2}$ was assessed by analysing the movement of larvae to within $20 \mathrm{~mm}$ of the point source using Fisher's exact $P$ test (Johnson et al., 2006). Larval behavioural response to constant $\mathrm{CO}_{2}$ atmospheres were assessed by analysing larval tracks using Fractal (v. 5.18.0) software (Nams, 1996). Fractal dimension is commonly used to interpret tracks left by animals (Doerr \& Doerr, 2004). A fractal is a geometric shape that has 'self similarity', meaning when divided into sections, each section looks like a smaller sized version of the original shape. The fractal dimension is a statistical quantity that indicates how completely the fractal fills space as the scale is reduced (Mandelbrot, 1967;

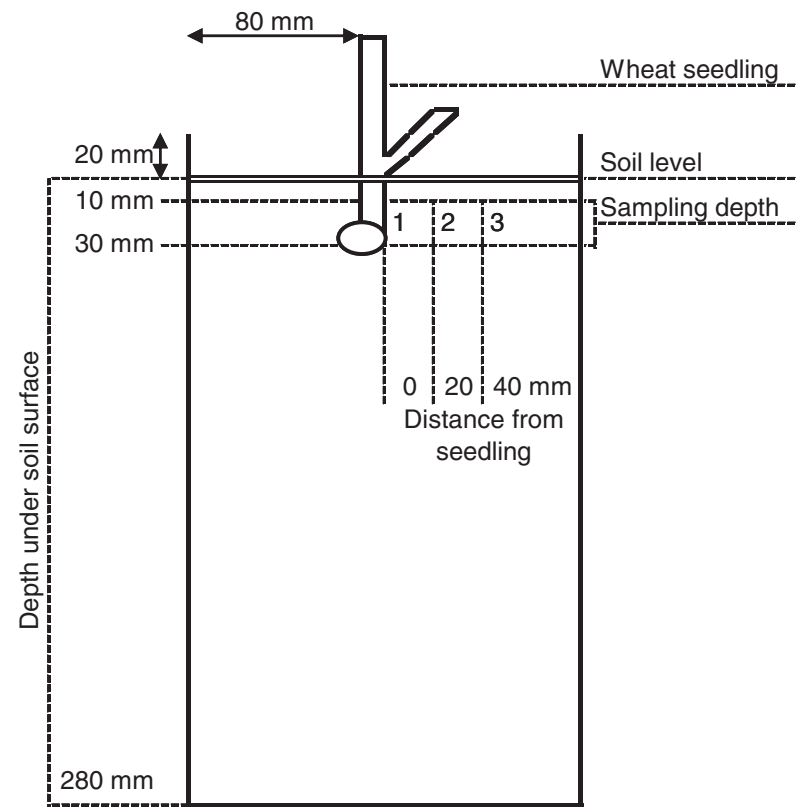

Fig. 2. Diagram of the setup and sampling positions for $\mathrm{CO}_{2}$ analysis of wheat seedlings grown within microcosms.

Milne, 1991). When analysing an animal track its fractal dimension is a measure of track tortuosity (how tortuous the track is i.e., how much it twists and turns) (Milne, 1997). The fractal dimension of a track lies between the values 1.0 and 2.0, with a value of 1.0 representing a track that is a straight line and 2.0 being a tortuous track that completely covers a plane (Nams, 1996).

Tracks that are produced in heterogeneous environments will show direct lines from resource to resource with tortuous sections within each resource patch, and not display selfsimilarity (Wiens et al., 1995). The assumption that the environment in the arena was homogeneous was tested by examination of the correlation between track length (number of fractal dividers) and the fractal divider size. If the relationship between the track length and the divider size conforms to a power-law relationship, then it is seen to be scale-invariant, displaying self-symmetry (Mandelbrot, 1983), therefore laid by larvae experiencing a homogeneous environment (Johnson et al., 2006).

Fractal dimension (FD, a dimensionless quantity) and length $(\mathrm{mm})$ were calculated for each track using Fractal (v. 5.18.0) software (Nams, 1996) and transformed by $\log _{10}$ and square root respectively to normalize the data (tested by an Anderson-Darling test), as a normal distribution is a requirement for analysis by one-way analysis of variance (ANOVA) (Fowler et al., 1998). Fractal dimension values and track length were analysed with ANOVA, with post-hoc comparisons by Tukey's test (Johnson et al., 2006), and finally 95\% confidence intervals (CI) were calculated. All statistics were conducted using Minitab statistical software version 15 (Minitab Inc.). The number of individuals tested for each treatment was 20.

\section{$\mathrm{CO}_{2}$ concentration in soil, sample collection}

Germinated wheat seedlings (cv. Aristos) were planted at the depth of $30 \mathrm{~mm}$ in top soil (packed to a bulk density of 


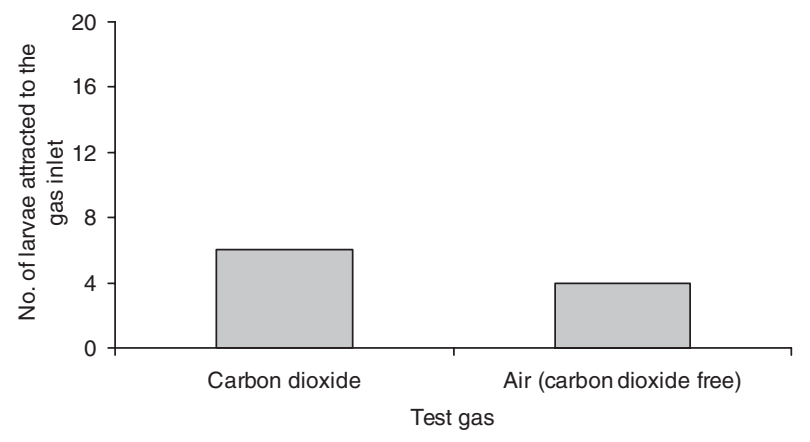

Fig. 3. Number of WBF larvae that moved to within $20 \mathrm{~mm}$ of the gas inlet in arenas, introducing either $\mathrm{CO}_{2}$ or $\mathrm{CO}_{2}$-free air (the control), at a rate of $8 \mathrm{mlh}^{-1}, N=20$.

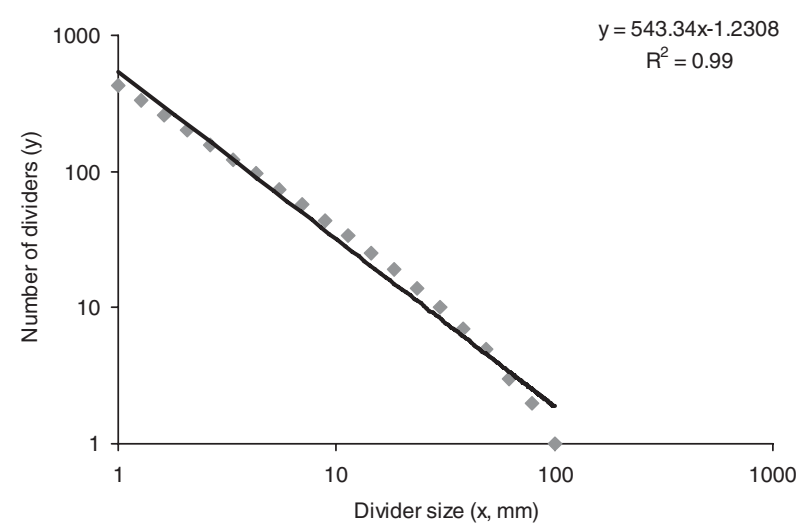

Fig. 4. Power-law relationship between number of dividers (track length) and divider size ( $\mathrm{mm}) . R^{2}=$ coefficient of determination.

$\left.1.2 \mathrm{~g} \mathrm{~cm}^{-3}\right)$ in the centre of cylindrical containers measuring $160 \mathrm{~mm}$ in diameter and $130 \mathrm{~cm}$ in height (fig. 2). The seedlings were grown in these microcosms, housed in Snijdes Scientific (Microclima 1000E) growth cabinets under the following conditions: a constant light and dark period temperature of $12: 7^{\circ} \mathrm{C}$, respectively; a photoperiod of 12:12 (light:dark); light intensity of 12,000 Lux; relative humidity of $\geq 50 \%$. The wheat seedlings were grown for 11 days, individual microcosms were weighed at regular intervals and watered gravimetrically to maintain soil moisture at $45 \%$. After 11 days microcosms were sealed using parafilm and left to stand for $1 \mathrm{~h}$. Gas samples, $11 \mathrm{ml}$ in volume, were taken from sampling ports using a sterile syringe to analyse the $\mathrm{CO}_{2}$ concentration. A sampling port was situated at either: 0,20 or $40 \mathrm{~mm}$ distance from the seedling at a depth of between 10 and $30 \mathrm{~mm}$ (fig. 2). A single distance was sampled from each microcosm, with each distance replicated eight times.

\section{Analysis through gas chromatography}

$\mathrm{CO}_{2}$ samples were analysed using a Hewlett Packard Series II 5890 gas chromatograph (GC), utilizing a thermal conductivity detector (TCD). Column temperature was held at $45^{\circ} \mathrm{C}$ throughout the analysis (total run time approximately $3 \mathrm{~min}$, per sample). The injector temperature was $35^{\circ} \mathrm{C}$, with an injection volume of $1 \mathrm{ml}$. The carrier gas was hydrogen (BOC,

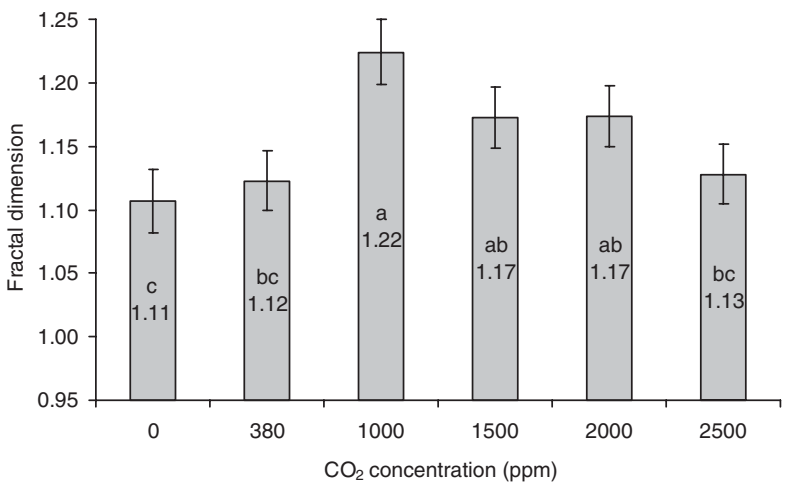

Fig. 5. Mean fractal dimensions (back-transformed) ( $\pm 95 \%$ CI) of tracks laid by WBF larvae exposed to different concentrations of $\mathrm{CO}_{2}: 0,380$ (atmospheric), 1000, 1500, 2000, 2500 ppm. The greater the fractal dimension value, the more tortuous the path taken, $N=20$. Statistical differences between groups are indicated by differing lower case letters (one-way ANOVA post-hoc comparisons by Tukey's test).

UK), the calibration standards (390; 1093; 5262; 10,100 ppm $\mathrm{CO}_{2}$ were supplied by $\left.\mathrm{BOC}, \mathrm{UK}\right)$ were run in triplicate. The mean of the two most similar results were taken and plotted to produce a linear standard curve so as to estimate the unknown samples.

\section{Results \\ $\mathrm{CO}_{2}$ as an attractant}

Analysis of arena bioassays offering a constant stream of $\mathrm{CO}_{2}$ or $\mathrm{CO}_{2}$-free air at $8 \mathrm{ml} \mathrm{h}^{-1}$ showed no significant difference in larval numbers entering a $20 \mathrm{~mm}$ radius of the inlet (fig. 3) when analysed using Fisher's exact test $(P=0.716)$.

\section{$\mathrm{CO}_{2}$ as a behavioural modifier}

When assessing the larval behavioural response to constant $\mathrm{CO}_{2}$ concentrations through analysis of track fractal dimensions, the assumption was made that the habitat (arena) encountered by the larvae was homogeneous in nature. If this was the case then the relationship between the 'number of dividers' (track length) and 'divider size' would be scale invariant (scaling divider size by a constant causes a proportionate scaling of the track length). This was demonstrated by plotting track length and the divider size, proportionate scaling was observed as track length and the divider size conformed to a power-law relationship $\left(R^{2}=0.99\right)$ (fig. 4). This scale-invariant relationship meant that larvae did not encounter a heterogeneous environment in the arenas, i.e., the atmosphere in arena was homogeneous.

Fractal dimension and distance of track data were normally distributed when transformed by $\log _{10}$ and square root, respectively. ANOVA conducted on the fractal dimension data showed that there were significant differences within the group of $\mathrm{CO}_{2}$ concentrations: $F_{5,114}=8.38 ; P<0.001$. Tukey's post-hoc test provided information on which groups were significantly different from each other (fig. 5). Larval tracks produced in the elevated $\mathrm{CO}_{2}$ concentration level of $1000 \mathrm{ppm}$ (fig. 6a) were shown to be significantly more tortuous than those produced under 0 (fig. $6 \mathrm{~b}$ ) or $380 \mathrm{ppm}$ 
(a)

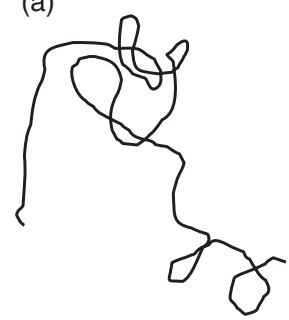

(b)

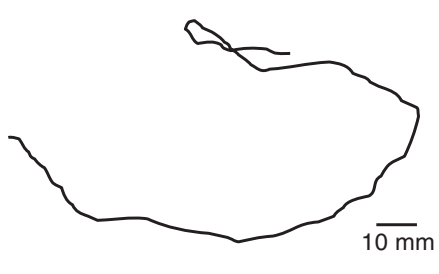

Fig. 6. Track of WBF larva made in an arena with a homogeneous atmosphere containing (a) $1000 \mathrm{ppm} \mathrm{CO}_{2}$. The track displays higher tortuosity (higher fractal dimension, $\mathrm{FD}=1.3$ ), indicating the animal was travelling within a resource; (b) $0 \mathrm{ppm} \mathrm{CO}_{2}$. The track displays low tortuosity (low fractal dimension, $\mathrm{FD}=1.1$ ), indicating the animal was travelling between resources.

$\mathrm{CO}_{2}$ concentrations $(P<0.001$ and $<0.001$, respectively), and also more so than the highest concentration tested, $2500 \mathrm{ppm}$ $(P<0.001)$. Although not as pronounced, the higher concentrations of $\mathrm{CO}_{2} ; 1500 \mathrm{ppm}(P=0.024)$ and $2000 \mathrm{ppm}(P=0.021)$, were significantly more tortuous than those produced under a 0 ppm $\mathrm{CO}_{2}$ environment.

ANOVA of track distance data collected under different constant $\mathrm{CO}_{2}$ concentrations also showed significant differences between treatments; $F_{5,114}=5.70, P<0.001$. The post-hoc Tukey's test highlighted significant differences between track lengths (fig. 7); tracks formed under the 1000 ppm $\mathrm{CO}_{2}$ environment were significantly longer than those formed under the $0(P=0.018), 380(P=0.042)$ and $2500 \mathrm{ppm}(P \leq 0.001)$ environments. The length of tracks produced under a $\mathrm{CO}_{2}$ concentration of $1500 \mathrm{ppm}$ were significantly longer than those produced under 0 ppm conditions $(P=0.021)$, whereas tracks formed under 1500 and $2000 \mathrm{ppm}$ conditions were significantly longer than those created under $2500 \mathrm{ppm} \mathrm{CO}_{2}$ $(P=0.004$ and 0.04 , respectively).

\section{Seedling derived $\mathrm{CO}_{2}$ concentration in soil}

Soil $\mathrm{CO}_{2}$ gradients were assed using GC analysis of gas samples removed at set distances from wheat seedlings, with the hypothesis that $\mathrm{CO}_{2}$ concentration in the soil would increase with proximity to the seedling. The data collected were not normally distributed; therefore a non-parametric Kruskal-Wallis test was used to compare the median $\mathrm{CO}_{2}$ concentrations from the three distance categories sampled $(0,20$ and $40 \mathrm{~mm})$ (fig. 8). A trend was noted for a decrease in the concentration of $\mathrm{CO}_{2}$ as the sampling distance increased. However, analysis through the Kruskal-Wallis test reported no significant change in the $\mathrm{CO}_{2}$ concentrations in relation to distance from the seedling: $H=2.94,2$ d.f., $P=0.229$.

\section{Discussion}

It was observed that WBF larvae produced more tortuous and longer tracks when exposed to $\mathrm{CO}_{2}$ concentrations of $1000 \mathrm{ppm}$ than when exposed to concentrations of 0 and 380 ppm (atmospheric). A trend was observed for tracks to be longer and more tortuous at $\mathrm{CO}_{2}$ levels above $380 \mathrm{ppm}$, but these were not always significant at the 1500 and $2000 \mathrm{ppm}$ levels, up until 2500 ppm where track tortuosity and length returned to a similar level to that found under 0 and $380 \mathrm{ppm}$ conditions. When presented with a point source of $\mathrm{CO}_{2} \mathrm{WBF}$

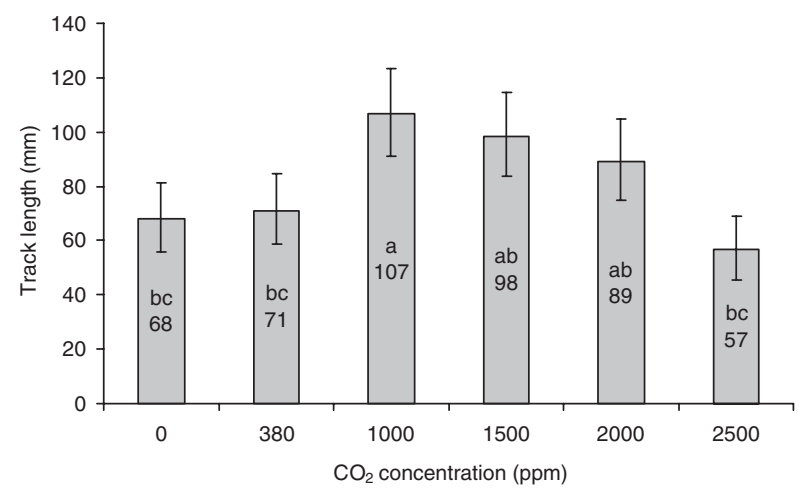

Fig. 7. Mean length (back-transformed) $(\mathrm{mm} \pm 95 \% \mathrm{CI})$ of tracks laid by WBF larvae exposed to different constant concentrations of $\mathrm{CO}_{2}: 0,380$ (atmospheric), 1000, 1500, 2000, 2500 ppm, $N=20$. Statistical differences between groups are indicated by differing lower case letters (one-way ANOVA, post-hoc comparisons by Tukey's test).

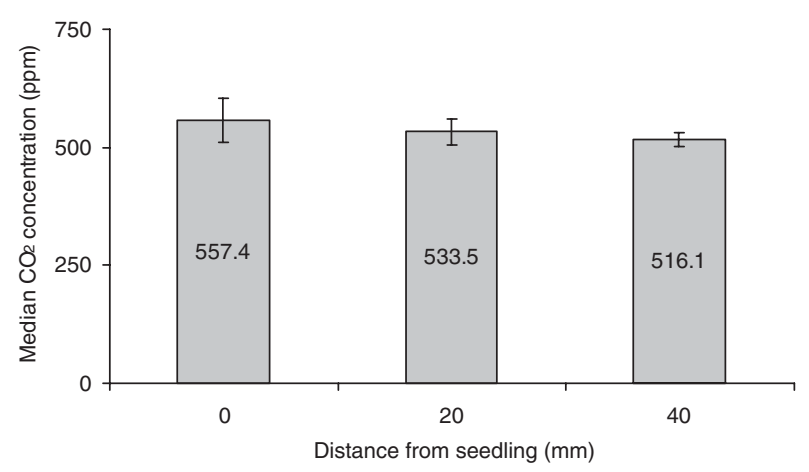

Fig. 8. Median concentration of $\mathrm{CO}_{2}(\mathrm{ppm} \pm 95 \% \mathrm{CI})$ detected from sampling ports situated at: 0,20 and $40 \mathrm{~mm}$ distances from wheat seedlings, $N=8$.

larvae did not orientate within $20 \mathrm{~mm}$ of the source significantly more frequently than when presented with air containing 0 ppm $\mathrm{CO}_{2}$, indicating that larvae are not attracted to a point source of $\mathrm{CO}_{2}$.

These results suggest that $\mathrm{WBF}$, like many other phytophagous larvae, utilize $\mathrm{CO}_{2}$ to aid in the location of hostplants. As a primary metabolite, $\mathrm{CO}_{2}$ is produced by all plants (Taiz \& Zeiger, 2010) and is the most abundant gas released from plant roots (Payne \& Gregory, 1988). For many less specific polyphagous species locating the nearest host-plant could be a relatively simple undertaking through following $\mathrm{CO}_{2}$ emissions alone. However, monophagous and oligophagous larvae need to be more selective when it comes to locating food sources. Oligophagous larvae such as WBF would be less likely to locate a host-plant by merely following $\mathrm{CO}_{2}$ gradients in the soil, due to there being more $\mathrm{CO}_{2}$ sources in the soil than their host-plant alone; therefore it is unsurprising that attraction to this compound was not observed in this study. Johnson et al. (2006) found that the monophagous weevil S. lepidus also did not show a directional response to $\mathrm{CO}_{2}$, but did observe increased movement tortuosity similar to that which was observed in WBF during this 
study. This increase in searching behaviour by $S$. lepidus was noted at a concentration of $1000 \mathrm{ppm} \mathrm{CO}_{2}$, the same concentration as was found to induce the greatest tortuosity and track length in WBF larvae. It was also demonstrated that 1000 ppm was similar to the $\mathrm{CO}_{2}$ concentration found surrounding the roots of the clover host-plant (Johnson et al., 2006). When sampling $\mathrm{CO}_{2}$ levels in soil around wheat seedlings in this study, it was noted that there was a trend for higher concentrations of $\mathrm{CO}_{2}$ close to the seedling, which reduced with distance. However, statistical analysis did not show this as significant. The relatively low level of observed $\mathrm{CO}_{2}$ at close proximity to the plant, compared with the Johnson et al. study, could be put down to the lack of a mesh screen in the microcosms, as these limit the spread of the roots, and were used in that and other similar studies (Johnson et al., 2006). By limiting the spread of the root system, such screens keep the roots closer to the sampling sites and potentially result in a higher and more consistent soil concentration of $\mathrm{CO}_{2}$. The level of $\mathrm{CO}_{2}$ found near the seedling was less than the lowest concentration found to stimulate the larvae (1000 ppm) and was greater than the highest concentration that did not stimulate the larvae (380 ppm).

Host-plant locations in Diabrotica spp. have been extensively studied, and both hydroxamic acids (Bjostad \& Hibbard, 1992) and $\mathrm{CO}_{2}$ (Jewett \& Bjostad, 1996) have been identified as attractive, with $\mathrm{CO}_{2}$ being the primary chemical attractant involved in host-plant location (Bernklau \& Bjostad, 1998). The hypothesis of $\mathrm{CO}_{2}$ being the primary attractant utilized by host-finding larvae is plausible for Diabrotica spp. as adult females oviposit in fields of corn, the larval host-plant (Levine \& Oloumi-Sadeghi, 1991). The larvae are more likely to hatch in close proximity to their host-plant, therefore simply orientating along $\mathrm{CO}_{2}$ gradients is more likely to locate them a host-plant. This scenario appears to be too simplistic a method of host-plant location in WBF, given the complex ecology associated with oviposition in this species, resulting from the lack of association between oviposition sites and larval hostplants (Petherbridge, 1921).

These results suggest that $\mathrm{WBF}$ larvae do not use $\mathrm{CO}_{2}$ gradients to locate host-plants. However, $\mathrm{CO}_{2}$ does induce a behavioural response from the larvae. $\mathrm{As}^{\mathrm{CO}_{2}}$ gradients in soil are unstable due to microbial interactions, pore structures and interaction with the atmosphere (Gollany et al., 1993; Hanson et al., 2000; Sheppard \& Lloyd, 2002), combined with the ubiquitous nature of $\mathrm{CO}_{2}$ emission by plants (Taiz \& Zeiger, 2010), it makes host-plant location by this method unlikely for an oligophagous larvae such as WBF. WBF larvae are stimulated by increased $\mathrm{CO}_{2}$ levels in the soil; however, instead of being induced to orientate with respect to the gradient, they are induced to perform searching behaviour, such as an increase in turning as indicated by the increased tortuosity of the track or increased track length. Once induced to search, the larvae would then rely more on family or genusspecific chemicals to locate and identify their host-plant such as the hydroxamic acids DIMBOA (2,4-dihydroxy-7-methoxy1,4-benzoxazin-3-one) and MBOA (6-methoxybenzoxazolinone), which have been found to be attractive (Rogers, 2011; Rogers \& Evans, 2013).

$\mathrm{CO}_{2}$ has been identified as a target compound for controlling a number of insect species deleterious to human health, mainly to control parasitic dipterans (DeFoliart \& Morris, 1967) including Tabanidae (horse flies, Hayakawa, 1988), Culicoides impunctatus (Highland midge, Bhasin et al., 2001) and Triatoma infestans (kissing bug, Barrozo \& Lazzari,
2004). $\mathrm{CO}_{2}$ baited traps have been proposed to lure and kill mosquitoes (Williams et al., 2006) and Culicoides midges (Nelson, 1965), while the targeting of $\mathrm{CO}_{2}$ receptors with chemical inhibitors and activators to disrupt host-finding behaviour of mosquitoes has also been proposed (Turner $\mathrm{et}$ al., 2011). Attracting larvae or disrupting searching behaviour underground through the creation of $\mathrm{CO}_{2}$ lures and false $\mathrm{CO}_{2}$ gradients has been discussed (Bernklau et al., 2004), although it is both impractical and counter to the current move to curb agricultural output of greenhouse gasses such as $\mathrm{CO}_{2}$. However, the use of chemicals that over stimulate or block the $\mathrm{CO}_{2}$ receptors of larvae could be developed. Work with lepidopteran pests has shown that exposing adult males to high levels of sex pheromone can render the moth incapable of locating female conspecifics (Nansen et al., 2007); this can be due to over excitation of the sensory receptors causing sensory fatigue or by competing with natural pheromone plumes (Cardé \& Minks, 1995). The principles behind this 'mating disruption' method of control could also be adapted for use to control host-finding phytophagous larvae, by using the chemical inhibitors and activators of $\mathrm{CO}_{2}$ receptors reported by Turner et al. (2011) or similar. Through this method, larval host finding could be disrupted, inducing larvae to waste valuable resources by increasing their activity unnecessarily or by preventing them locating host-plants by blocking their perception of $\mathrm{CO}_{2}$ gradients. Larval host finding in WBF is a critical period given the lack of associated host-plant when adults select oviposition sites. Larvae must locate a host-plant rapidly to avoid predation and to avoid death through starvation. If $\mathrm{CO}_{2}$ gradients could be disrupted through the addition of compounds that sequester $\mathrm{CO}_{2}$ or if the perception of these gradients were removed through disruption of larval $\mathrm{CO}_{2}$ receptors, then there would be a greater chance of larval mortality during their vulnerable host finding stage. The study of insect chemical ecology has been investigated for a number of subterranean phytophagous larvae. However, unlike above ground herbivorous insect pests, little has been done to utilize these results within pest management systems.

\section{Acknowledgement}

C.D. Rogers was financially supported by a Home Grown Cereals Authority (HGCA) studentship.

\section{References}

Adler, J. (1966) Chemotaxis in bacteria. Science 153, 708-716.

Barrozo, R.B. \& Lazzari, C.R. (2004) The response of the bloodsucking bug Triatoma infestans to carbon dioxide and other host odours. Chemical Senses 29, 319-329.

Bellows, T.S. \& Fisher, T.W. (1999) Handbook of Biological Control: Principles and Applications. San Diego, Academic Press.

Bernklau, E.J. \& Bjostad, L.B. (1998) Reinvestigation of host location by western corn rootworm larvae (Coleoptera: Chrysomelidae): $\mathrm{CO}_{2}$ is the only volatile attractant. Journal of Economic Entomology 91, 1331-1340.

Bernklau, E.J., Fromm, E.A. \& Bjostad, L.B. (2004) Disruption of host location of western corn rootworm larvae (Coleoptera: Chrysomelidae) with carbon dioxide. Journal of Economic Entomology 97, 330-339.

Bhasin, A., Mordue, A.J. \& Mordue, W. (2001) Field studies on efficacy of host odour baits for the biting midge Culicoides impunctatus in Scotland. Medical and Veterinary Entomology 15, 147-156. 
Bjostad, L.B. \& Hibbard, B.E. (1992) 6-methoxy-2-benzoxazolinone a semiochemical for host location by western corn rootworm larvae. Journal of Chemical Ecology 18, 931-944.

Cardé, R.T. \& Minks, A.K. (1995) Control of moth pests by mating disruption: success and constraints. Annual Review of Entomology 40, 559-585.

DeFoliart, G.R. \& Morris, G.D. (1967) A dry ice-baited trap for the collection and field storage of hematophagous Diptera. Journal of Medical Entomology 4, 360-363.

Doerr, V.J. \& Doerr, E.D. (2004) Fractal analysis can explain individual variation in dispersal search paths. Ecology 85, 1428-1438.

Eisenbach, M. (2004) Chemotaxis. London, Imperial College Press.

Fowler, J., Cohen, L. \& Jarvis, P. (1998) Practical Statistics for Field Biology. Chichester, John Wiley \& Sons Ltd.

Galbreath, R.A. (1988) Orientation of grass grub Costelytra zealandica (Coleoptera: Scarabaeidae) to a carbon dioxide source. New Zealand Entomologist 11, 6-7.

Gillott, C. (2005) Entomology, 3rd edn. Dordrecht, Springer.

Gollany, H.T., Schumacher, T.E., Rue, R.R. \& Liu, S.Y. (1993) A carbon dioxide microelectrode for in situ $\mathrm{CO}_{2}$ measurement. Microchemical Journal 48, 42-49.

Greenway, A.R., Scott, G.C., Calam, D.H. \& Smith, M.C. (1976) Chemistry of components in wheat and oats that influence behaviour of wheat bulb fly larvae. Journal of Insect Physiology 22, 445-451.

Hanson, P.J., Edwards, N.T., Garten, C.T. \& Andrews, J.A. (2000) Separating root and soil microbial contributions to soil respiration: a review of methods and observations. Biogeochemistry 48, 115-146.

Hayakawa, H. (1988) Relationship between the volume of carbon dioxide and the effectiveness in collecting tabanid flies. Japanese Journal of Sanitary Zoology 39, 313-315.

Hiltpold, I. \& Turlings, T.C.J. (2012) Manipulation of chemically mediated interactions in agricultural soils to enhance the control of crop pests and to improve crop yield. Journal of Chemical Ecology 38, 641-650.

Honda, I. \& Ishikawa, Y. (1987) Electrophysiological studies on the dorsal and anterior organs of the onion fly larva, Hylemya antiqua Meigen (Diptera, Anthomyiidae). Applied Entomology and Zoology 22, 410-416.

Hopkins, R.J., Griffiths, D.W., Birch, A.N.E., McKinlay, R.G. \& Hall, J.E. (1993) Relationships between turnip root fly (Delia floralis) larval development and the sugar content of swede (Brassica napus ssp. rapifera) roots. Annals of Applied Biology 122(3), 405-415.

Huang, X.P. \& Mack, T.P. (2001) Artificial carbon dioxide source to attract lesser cornstalk borer (Lepidoptera: Pyralidae) larvae. Journal of Economic Entomology 94(4), 860-867.

Jewett, D.K. \& Bjostad, L.B. (1996) Dichloromethane attracts diabroticite larvae in a laboratory behavioral bioassay. Journal of Chemical Ecology 22(7), 1331-1344.

Johnson, S.N. \& Gregory, P.J. (2006) Chemically-mediated host-plant location and selection by root-feeding insects. Physiological Entomology 31(1), 1-13.

Johnson, S.N. \& Nielsen, U.N. (2012) Foraging in the darkchemically mediated host plant location by belowground insect herbivores. Journal of Chemical Ecology 38(6), 604-614.

Johnson, S.N., Zhang, X.X., Crawford, J.W., Gregory, P.J., Hix, N.J., Jarvis, S.C., Murray, P.J. \& Young, I.M. (2006) Effects of carbon dioxide on the searching behaviour of the root-feeding clover weevil Sitona lepidus
(Coleoptera: Curculionidae). Bulletin of Entomological Research 96(4), 361-366.

Jones, O.T. \& Coaker, T.H. (1977) Oriented responses of carrot fly larvae, Psila rosae, to plant odours, carbon dioxide and carrot root volatiles. Physiological Entomology 2(3), 189-197.

Jones, O.T. \& Coaker, T.H. (1978) A basis for host plant finding in phytophagous larvae. Entomologia Experimentalis et Applicata 24, 272-284.

Klingler, J. (1957) Über die bedeutung des kohlendioxyds für die orientierung der larven von Otiorrhynchus sulcatus F., Melolontha und Agriotes (Col.) im boden (Vorlaufige mitteilung). Mitteilungen der Schweizerischen Entomologischen Gesellschaft 30, 317-322.

Levine, E. \& Oloumi-Sadeghi, H. (1991) Management of diabroticite rootworms in corn. Annual Review of Entomology 36, 229-255.

Mandelbrot, B. (1967) How long is the coast of Britain? Statistical self-similarity and fractional dimension. Science 156, 636-638.

Mandelbrot, B.B. (1983) The Fractal Geometry of Nature. New York, W.H. Freeman and Co.

Marriott, C. (2001) Host plant location, selection and preference by wheat bulb fly Delia coarctata Fall. (Diptera: Anthomyiidae). PhD Thesis, University of Edinburgh.

Marriott, C. \& Evans, K.A. (2003) Host plant choice and location by larvae of the wheat bulb fly (Delia coarctata). Entomologia Experimentalis et Applicata 106(1), 1-6.

Milne, B.T. (1991) Lessons from applying fractal models to landscape patterns. pp. 199-235 in Turner, M.G. \& Gardner, R.H. (Eds) Quantitative Methods in Landscape Ecology. New York, Springer.

Milne, B.T. (1997) Applications of fractal geometry in wildlife biology. pp. 32-69 in Bissonette, J.A. (Ed.) Wildlife and Landscape Ecology. New York, Springer-Verlag.

Morris, H.M. (1925) Note on the wheat bulb fly (Leptohylemyia coarctata, Fall.). Bulletin of Entomological Research 15, 359-360.

Nams, V.O. (1996) The VFractal: a new estimator for fractal dimension of animal movement paths. Landscape Ecology 11(5), 289-297.

Nams, V.O. (2005) Using animal movement paths to measure response to spatial scale. Oecologia 143, 179-188.

Nansen, C., MacDonald, K.M., Rogers, C.D., Thomas, M., Poppy, G.M. \& Baxter, I.H. (2007) Effects of sex pheromone in electrostatic powder on mating behaviour by Lobesia botrana males. Journal of Applied Entomology 131(5), 303-310.

Nelson, R.L. (1965) Carbon dioxide as an attractant for Culicoides. Journal of Medical Entomology 2(1), 56-57.

Payne, D. \& Gregory, P.J. (1988) The soil atmosphere. pp. 298-314 in Wild, A. (Ed.) Russell's Soil Conditions and Plant Growth. Harlow, Longman.

Petherbridge, F.R. (1921) Observations on the life history of the wheat-bulb fly Leptohylenyia coarctata, Fall. Journal of Agricultural Science 11, 99-105.

Rogers, C.D. (2011) Ecological and molecular investigation of wheat bulb fly (Delia coarctata, Fallén, Diptera: Anthomyiidae) for the advancement of population monitoring and control methodologies. PhD Thesis, University of Edinburgh.

Rogers, C.D. \& Evans, K.A. (2013) Wheat bulb fly (Delia coarctata, Fallén, Diptera: Anthomyiidae) larval response to hydroxamic acid constituents of host-plant root exudates. Bulletin of Entomological Research 103(3), 261-268.

Scott, G.C. (1974) The response of wheat bulb fly larvae to cereal exudates and extracts. Annals of Applied Biology 77(1), 107-111. 
Sheppard, S.K. \& Lloyd, D. (2002) Direct mass spectrometric measurement of gases in soil monoliths. Journal of Microbiological Methods 50, 175-188.

Stokes, B.M. (1956) A chemotactic response in wheat bulb fly larvae. Nature 178, 801.

Strnad, S.P., Bergman, M.K. \& Fulton, W.C. (1986) First instar western corn rootworm (Coleoptera, Chrysomelidae) response to carbon dioxide. Environmental Entomology 15(4), 839-842.

Taiz, L. \& Zeiger, E. (2010) Plant Physiology. Sunderland, Sinauer Associates Inc.

Tepe, J.B. \& Dodge, B.F. (1943) Absorption of carbon dioxide by sodium hydroxide solutions in a packed column. Transactions of the American Institute of Chemical Engineers 39, 255.

Thorpe, W.H., Crombie, A.C., Hill, R. \& Darrah, J.H. (1947) The behaviour of wireworms in response to chemical stimulation. Journal of Experimental Biology 23(3-4), 234-266.

Turlings, T.C.J., Hiltpold, I. \& Rasmann, S. (2012) The importance of root-produced volatiles as foraging cues for entomopathogenic nematodes. Plant Soil 358(1), 51-60.

Turner, S.L., Li, N., Guda, T., Githure, J., Cardé, R.T. \& Ray, A. (2011) Ultra-prolonged activation of $\mathrm{CO}_{2}$-sensing neurons disorients mosquitoes. Nature 474, 87-91.

Way, M.J. (1959) The effect of temperature, particularly during diapause, on the development of the egg of Leptohylemyia coarctata Fallen (Diptera: Muscidae). Transactions of the Royal Entomological Society of London 111(12), 351-364.

Wiens, J.A., Crist, T.O., With, K.A. \& Milne, B.T. (1995) Fractal patterns of insect movement in microlandscape mosaics. Ecology 76, 663-666.

Williams, C.R., Long, S.A., Russell, R.C. \& Ritchie, S.A. (2006) Field efficacy of the BG-Sentinel compared with CDC Backpack Aspirators and $\mathrm{CO}_{2}$-baited EVS traps for collection of adult Aedes aegypti in Cairns, Queensland, Australia. Journal of the American Mosquito Control Association 22(2), 296-230. 